\title{
AHCA meets BCRA; timeline, context, and future directions
}

\author{
Joshua A Hirsch, ${ }^{1}$ Andrew B Rosenkrantz, ${ }^{2}$ Bibb Allen, ${ }^{3}$ Greg N Nicola, ${ }^{4}$ \\ Richard P Klucznik, ${ }^{5}$ Laxmaiah Manchikanti ${ }^{6}$
}

${ }^{1}$ Department of

Neurolnterventional Radiology, Massachusetts General Hospital Harvard Medical School, Boston, Massachusetts, USA

${ }^{2}$ Department of Radiology, New York University Langone Medical Center, New York, USA

${ }^{3}$ Department of Radiology, Grandview Medical Center Birmingham, Alabama, USA ${ }^{4}$ Hackensack University Medical Center, Hackensack Radiology Group, Hackensack, New Jersey, USA

${ }^{5}$ Methodist Hospital, Houston, Texas, USA

${ }^{6}$ Department of Anesthesiology and Perioperative Medicine,

Pain Management Center of

Paducah, University of Louisville, Paducah, Kentucky, USA

\section{Correspondence to}

Dr Joshua A Hirsch, Department of Neurolnterventional Radiology, Massachusetts General Hospital, Harvard Medical School, Boston, Massachusetts 02114, USA; hirsch@snisonline.org

Accepted 11 September 2017 Published Online First 28 September 2017

\section{CrossMark}

To cite: Hirsch JA, Rosenkrantz $A B$, Allen $B$, et al J Neurolntervent Surg 2018;10:205-208

\section{INTRODUCTION}

This past decade has brought important change to the delivery of healthcare in the United States. In 2010, President Barack Obama signed the Patient Protection and Affordable Care Act (PPACA, also referred to as ACA or Obamacare) into law. ${ }^{1}$ The ACA sought to provide insurance for millions of additional Americans while simultaneously bending the cost curve down. ${ }^{2}$ Beyond that, the far-ranging law imposed new taxes, developed new independent agencies with heightened power in shaping healthcare policy and regulations, and advanced the implementation of accountable care. ${ }^{3-5}$

In response to the Congressional vote passing the ACA along strict party lines, Republicans have repeatedly emphasized their desire to undo the legislation and replace it with something they considered better. The Republican Congress subsequently undertook multiple votes to repeal the ACA throughout the remainder of the Obama administration. Nonetheless, even if successful in passing Congress, all such efforts were guaranteed to be vetoed by the President.

In January 2015, Secretary of Health and Human Services Sylvia Burwell described the administration's priority of transitioning volume-based care to a system providing greater value, ${ }^{67}$ and a whole new industry was formed to manage this transition. ${ }^{8}$ Throughout this period, a legion of other regulatory issues was confronting healthcare practitioners, ranging from ICD-10 implementation to meaningful use. ${ }^{10}$ One such perennial issue was the need to implement a fix to prevent enormous cuts to Medicare payments resulting from the sustainable growth rate formula for Part B services. ${ }^{11} 12$ In April 2015, the Medicare Access and CHIP Reauthorization Act of 2015 (MACRA) was passed, permanently ending the sustainable growth rate. ${ }^{13} 14$ However, MACRA, which has been described in numerous dedicated reviews, ${ }^{15} 16$ introduced an array of new challenges for providers, beneficiaries, and payers alike. ${ }^{1718}$

It is generally agreed that there are challenges to the continued vitality of the ACA. Of particular note, working and middle class people who earn more than $400 \%$ over the poverty level are not eligible for the federal cost sharing subsidies and face potentially dramatic insurance premium increases. The exchanges that were established in order to support individual healthcare insurance have not enjoyed the type of success that the legislation's authors anticipated. Further, the employer mandates associated with the ACA have contributed to the estimated 6 million people who have lost healthcare insurance. However, the proposed paths to fixing it differ widely. ${ }^{19}$ Many Democrats believe the existing framework of the ACA could be improved by further government intervention to mitigate challenges faced by insurance carriers in providing coverage for pre-existing conditions in the insurance exchanges; whereas many Republicans favor ACA repeal with replacement legislation and generally less federal intervention.

November 2016 drastically changed the political landscape as the executive branch and both chambers of Congress were now led by Republicans. Healthcare quickly became the priority. ${ }^{20}$ A previous review in JNIS detailed the intricacies of the initial ACA repeal legislation passed by the House-namely, the American Healthcare Act (AHCA). ${ }^{21}$ Using the timeline format established by the UCSF/UC Hastings Consortium on Law, Science and Health Policy, that manuscript will be updated here. $^{22}$

\section{THE 2017 TIMELINE}

On 12 January in the Senate and then on 13 January in the House, Republicans casted votes that would allow subsequent legislation to use the budget reconciliation process to remove large elements of the ACA. ${ }^{23}$ On 20 January, just hours after being sworn into office, President Trump signed the Executive Order Minimizing the Economic Burden of the Patient Protection and ACA Pending Repeal that weakened regulations designed to enforce that law. $^{24}$

On 7 March the AHCA was introduced into the House of Representatives through the two standing committees with jurisdiction for healthcare: the House Energy and Commerce Committee and the House Ways and Means Committee. The next day, both committees approved the AHCA, which allowed the legislation to then be taken up by the full House. As with the ACA, this was done along strict party lines. On 12 March the Congressional Budget Office (CBO) estimated that 52 million Americans would become uninsured under the AHCA, including many who would simply choose not to purchase insurance absent a mandate. It is worth noting that critics have criticized the $\mathrm{CBO}$ for producing inaccurate cost estimates. The Trump administration and many supporters of 
the legislation took issue with the estimates that relate to these efforts to repeal and replace Obamacare. ${ }^{25}$

On 16 March the Budget Committee sent the AHCA bill to the House Floor. On 24 March the AHCA was pulled from the Floor by Speaker of the House Paul Ryan when it became clear that there were insufficient votes to pass the bill. At this point, many observers considered the AHCA to no longer be viable. ${ }^{21}$

On 6 April the federal 'invisible risk sharing programme' amendment was added to the AHCA Patient and State Stability Fund. ${ }^{26}$ Invisible risk sharing represents a prospective reinsurance program for those that are at risk of incurring high premiums. Two weeks later, on 20 April, the White House announced that there were efforts underway to revitalize the initially failed legislation.

On 24 April the MacArthur amendment allowed states to request a waiver from several requirements implemented under the ACA, which served to dramatically undermine the law appealing to House members of the highly conservative Freedom Caucus. ${ }^{27}$ On 3 May the Upton amendment created a fund of $\$ 8$ billion dollars that was designed to offset higher costs for individuals with pre-existing conditions; a requirement for Republican moderates. ${ }^{28}$ On 4 May, following this series of amendments, the House of Representatives passed the bill with a four-vote margin (217/213). ${ }^{22}$

On the same day that the House passed its bill, the Senate announced its intent to draft its own version of ACA repeal legislation. On 9 May the Senate created a 13-person working group for this bill, bypassing the Senate Committees on Finance and Health, Education, Labor and Pensions (HELP) that have jurisdiction for healthcare in the Senate. Although the working group included Senators with healthcare experience including the chairs of the Finance and HELP committees, it suffered from a distinct lack of diversity and, on its formation, public concern was raised regarding the fact that it consisted only of men, despite developing legislation with potential enormous impact on women's healthcare. On 19 June the bill was sent to the CBO, and a 'discussion draft' of the BCRA was released on 22 June. ${ }^{29}$ Multiple Republican Senators expressed concerns the day it was released for reasons that ranged from it being an insurance bailout to possible negative impacts on patients who were added to the insurance rolls through Medicaid expansion. On 26 June the CBO scored the BCRA noting that, by 2026, 22 million Americans would be uninsured compared with if the ACA remained in place. ${ }^{30}$ The next day the vote, which had been planned specifically to occur before the 4 July recess, was delayed. On 11 July the Senate leadership undertook the highly unusual move of delaying the August recess so that work might continue on the BCRA. ${ }^{22}$

The budget reconciliation process allows for specific types of legislation to be passed by simple majority. ${ }^{20}$ Given an anticipated 'no' vote by all Senate Democrats, the BRCA could receive at most two 'no' votes by Senate Republicans to pass. On 13 July, amendments were made to the Senate's discussion draft in hopes of garnering increased support. Notably the 'Cruz amendment' would allow insurers to provide alternative minimal coverage plans that were not allowed under the ACA. ${ }^{31}$ Nonetheless, almost immediately, Senators Rand Paul and Susan Collins indicated that they would not vote to proceed. On 17 July, when Senators Jerry Moran and Mike Lee also indicated their intention to withhold support, the vote was postponed. ${ }^{32}$ The next day, President Trump embraced a 'Repeal Only' approach that would 'let Obamacare fail'. ${ }^{33}$ Three Republican Senators announced on that same day that they could not support this approach. Senator McConnell surprised many observers by indicating on that day,
18 July, that he intended to call for a vote to proceed on the BCRA the week of 24 July. $^{22}$ Such a move would force Republicans to take a vote that risked anchoring them to a bill that was unlikely to pass.

On 19 July Senator John McCain was diagnosed with glioblastoma multiforme. ${ }^{34}$ Given the plan to pass any bill through reconciliation and the sense that there were already two firm 'no' votes among Republicans, this sad announcement added to the legislative challenges faced by Senate Republicans. That same day, the Senate posted the Obamacare Repeal Reconciliation Act (ORRA) that sought full repeal without offering a concurrent replacement. ${ }^{35}$ This bill was meant to challenge those in the Republican majority that had previously voted for very similar legislation during the Obama administration, but who appeared to be changing their mind now that their vote more truly counted (ie, cast in the setting of a President who would not veto it). On 20 July the Senate released an updated version of the BCRA that included the 13 July amendment without the portion supported by Senator Cruz. ${ }^{36}$

On 25 July Senator McConnell announced that, after 20 hours of debate, he would call for a vote on the repeal-without-replace legislation. ${ }^{20}$ As this had virtually no chance of passing, it would be followed by a vote on a version of the BCRA that included the Cruz amendment. As that was also expected to fail, the Senate would then call on members to vote for 'skinny repeal'. This parliamentary maneuver was designed to get the bill out of the Senate and into a conference with the House, creating an avenue for eventual success. The premise of 'skinny repeal' was to leave much of the ACA in place but to eliminate the employer and individual mandate as well as the medical device tax. The motion to proceed in voting on this succession of bills passed the Senate 51-50, with two Republican 'no' votes by Senators Collins and Murkowski. In support of the vote, a seemingly revitalized Senator McCain gave a rousing speech on the Senate floor, asking for bipartisanship in moving this process forward. ${ }^{22}$ The next day, the Senate 'Vote-O-Rama' began, and it quickly became clear that the 'skinny bill' was the only path forward. Many Republicans expressed concern with respect to the quality of that bill. On 27 July the Senate formally released the Healthcare Freedom Act (HCFA) as implementation of skinny repeal. ${ }^{37}$ In a season of high legislative drama around healthcare, that evening's Senate proceedings would be particularly memorable as Vice President Pence, who remained present in the chamber to break a hoped-for 50-50 tie-vote in the event of only two Republican 'no' votes, watched Senator John McCain vote against the bill, ensuring the defeat of the HCFA by a vote of 49-51. ${ }^{22}$

Soon after this legislative defeat, on 29 July, President Trump repeated his plan to destabilize the individual insurance markets by ending ACA subsidies. However, on 2 August, Republican Senator Alexander from Tennessee released a statement that the Senate would hold bipartisan hearings to stabilize the individual market. ${ }^{38}$

\section{THE PRESENT DAY}

At the time of writing, September 2017 looks to be a very busy month for Congress with hard deadlines in place for increasing the federal debt ceiling, passing a budget bill to avoid a looming federal shutdown, and avoiding expiration of the Children's Health Insurance Programme. Moreover, President Trump has repeatedly suggested that the federal government might curtail its subsidies for Obamacare era insurance products. This is all occurring in the context of the 2018 Obamacare insurance company exchange contracts needing to be finalized within the same month. 
Meanwhile, House members of the Freedom Caucus are attempting to resurrect a repeal-without-replace option. They are circulating a discharge petition that would bring the bill directly to the House floor for a vote. ${ }^{39}$ The challenge for this approach is that no Democrat or moderate Republican would likely support the bill.

In the Senate, an effort is underway to pass a bill through reconciliation that would end insurance exchange premium tax credits and expand Medicaid funding by 2020 to send the money back to the states where local control might allow for better focus in handling. ${ }^{40}$ Once again, the challenge is that moderate Republicans in the Senate object to slowing the growth of Medicaid expansion and other elements of this draft plan.

On the other side of the aisle, Senators Bernie Sanders and Elizabeth Warren are leading the call for a single payer healthcare system. ${ }^{41}$ This group is paradoxically emboldened by an evolution in public opinion that has emerged during the AHCA/BCRA debates and town halls. The increasing instability of the individual insurance marketplace, in part attributable to efforts by the executive branch to weaken the ACA, is helping supporters of a single payer system argue that private insurance has proven itself unworkable for many constituents.

\section{The road to bipartisan compromise}

Senator Lamar Alexander heads the US Senate HELP Committee. He and Patty Murray, a Democratic Senator from Washington, are working on legislation to secure the cost sharing subsidies and develop a reinsurance fund for people with high claims. Funding these priorities would cost approximately $\$ 25$ billion in 2018. A hearing on this legislation will occur in September. ${ }^{38}$ In prior works, several of the authors of this article have called for bipartisanship to secure reliable, cost effective healthcare. ${ }^{21}$ While this effort of the HELP Committee seems to take a practical approach to addressing issues impacting beneficiaries, it is unclear if Congress at large would be able to successfully act on it. As previously noted, Congressional Republicans were unable to easily unite disparate elements of their own party and pass legislation along strict party lines, and efforts at bipartisan solutions were neglected during the process. The prospects of rapidly achieving widespread bipartisan compromise this late in the process are questionable.

On 31 July the bipartisan Problem Solvers Caucus released a proposal to stabilize the individual healthcare market. The caucus, made up of 22 Democrats and 22 Republicans, is largely regarded as political centrists. The proposal calls for bringing subsidies into the appropriations process, arguably a response to the administration's threats to cut off these cost sharing reduction payments. Additionally, they would create a dedicated stability fund that states can use to reduce premiums and limit losses for providing coverage. This is designed to maintain support for a popular element of the ACA-namely, pre-existing conditions. Further, the groups propose raising the threshold on the requirement for employers to provide insurance to employees to businesses of 500 employees or more and repeal the medical device tax. $^{42}$

\section{DISCUSSION}

The ACA established the Center for Medicare and Medicaid Innovation (CMMI). ${ }^{43} 44$ As described previously, at least two initiatives of the CMMI had meaningful potential to directly impact neurointerventional specialists: the Medicare Shared Savings Programme (MSSP), which implemented accountable care organizations (ACOs), and the Bundled Payments for Care Improvement (BPCI). ${ }^{95}$ However, per CMS, MSSP has been a net drain on Medicare (\$216 million through 2015). ${ }^{46}$ In addition, BPCI Model 2 has demonstrated limited savings for cardiology and orthopedic surgeons, and its attempts to bundle spinal surgery have led to increased costs. Thus, the results of existing alternative payment models are mixed. ${ }^{47}$ Moreover, on 15 August, CMS cancelled two separate bundled payment models and dramatically cut the number of providers required to participate in a third. ${ }^{48}$ Collectively, these developments call into question the long-term impact of the CMMI in implementing effective value-driven accountable care.

The ACA established exchanges for people who did not qualify for Medicaid Expansion. ${ }^{1}$ The individual market serves a mere $7 \%$ of the population. Over the last few years, many private insurers have pulled out of the exchanges, which has left many of these beneficiaries with very limited options for insurance coverage. For lower income beneficiaries, federal subsidies support their purchase of insurance products on these exchanges. The costs to insurance companies and beneficiaries alike would rise significantly if the Trump administration were to end these subsidies, and it is understandable that, in the face of uncertainty, they would consider exiting the marketplace. The Kaiser Family Foundation recently released an optimistic report on the viability of this marketplace, but commented specifically about the uncertainty and consequences of a withdrawal of federal subsidies for the exchanges. ${ }^{49}$

Another consequence of a repeal of all or some of the ACA would be the potential loss of the ACA's essential health benefits. While some states may require more coverage, essential health benefits are a set of 10 categories of services health insurance that plans must cover under the ACA. These include physician services; inpatient, outpatient and emergency care; maternity and pediatric services; laboratory services; prescription drug coverage; pregnancy and newborn care; mental health services; rehabilitative services; and preventive services. ${ }^{50}$ Radiologists will note that the current law requires insurance companies to cover, with no out-of-pocket costs to patients, any preventive services that receive a rating of A or B from the US Preventive Services Task Force, including screening mammography, lung cancer screening, and colon cancer screening. ${ }^{51}$ While the rate for colorectal cancer screening using colonoscopy did not change under the ACA, the number of women being screened for breast cancer with mammography increased under the ACA. If this provision of the ACA was repealed, the decision for mandated insurance coverage with no co-pay could fall to the states and likely create disparities in available benefits and reinstatement of socioeconomic barriers to cancer screening and other preventive services.

\section{CONCLUSION}

Total healthcare spending in the USA surpassed \$3.4 trillion dollars in 2016. This represents 19\% of the country's gross domestic product. ${ }^{52}$ Observers largely agree that the current system needs repair. It remains to be seen the extent to which that repair will come through a modification of the traditional fee for service process ${ }^{53}{ }^{54}$ that neurointerventional specialists know well or through alternative payment models. ${ }^{55}$ The ACA transformed healthcare, but by not delivering on the promises made when enacted in 2010, it has served as a rallying cry for Republicans in multiple election cycles. The events of November 2016 created a meaningful chance that the Republicans would fulfill their multi-year campaign promise. However, it seems that policy makers have learnt what physicians have known along, that healthcare financing is indeed complicated. 
For our current political leaders, it remains elusive to find the intersection of the goals of providing healthcare for all those in need and maintaining reasonable cost to those who are healthy. While the opportunity for Congressional action seems to have largely passed by this point, it remains at least conceivable that ACA repeal could still be achieved through further political and legislative maneuvering. Regardless, the ACA continues to face problems that require attention. Although unlikely in the current political climate, such challenges may best be addressed by politicians from both parties working together.

Contributors JAH composed the original draft. All authors had an opportunity to provide substantive feedback from which revisions were made. All authors approved the final version of the manuscript.

Competing interests None declared.

Provenance and peer review Commissioned; internally peer reviewed.

(c) Article author(s) (or their employer(s) unless otherwise stated in the text of the article) 2018. All rights reserved. No commercial use is permitted unless otherwise expressly granted.

\section{REFERENCES}

1 Public Law No: 111-148: H.R. 3590. Patient protection and affordable care act, 2010.

2 Manchikanti L, Hirsch JA. Patient Protection and Affordable Care Act of 2010: a primer for neurointerventionalists. J Neurointerv Surg 2012;4:141-6.

3 Manchikanti L, Hirsch JA. The independent payment advisory board: impact on neurointerventionalists. J Neurointerv Surg 2012;4:468-72.

4 Hirsch JA, Barr RM, McGinty G, et al. Affordable care 2014: a tale of two boards. J Neurointerv Surg 2014;6:718-20.

5 Manchikanti L, Helm S, Hirsch JA. The evolution of the patient-centered outcomes research institute. J Neurointerv Surg 2012;4:157-62.

6 Burwell SM. Setting value-based payment goals-HHS efforts to improve U.S. health care. N Eng/ J Med 2015;372:897-9.

7 Hirsch JA, Leslie-Mazwi TM, Barr RM, et al. The Burwell roadmap. J Neurointerv Surg 2016:8:544-6.

8 Hirsch JA, Rosenkrantz AB, Allen B, et al. Foundational changes critical to payments for radiology services. J Am Coll Radiol 2017;14:875-81.

9 Meehan TM, Harvey HB, Duszak R, et al. Accountable care organizations: what they mean for the country and for neurointerventionalists. J Neurointerv Surg 2016;8:654-7

10 Hirsch JA, Nicola G, McGinty G, et al. ICD-10: history and context. AJNR Am J Neuroradiol 2016;37:596-9.

11 Hirsch JA, Rosman DA, Liu RW, et al. Sustainable growth rate 2013: time for definitive intervention. J Neurointerv Surg 2013;5:382-6.

12 Hirsch JA, Manchikanti L. The sustainable growth rate: a 2014 update. J Neurointerv Surg 2014;6:411-2.

13 The Medicare Access and CHIP Reauthorization Act of 2015. http://www.congress. gov/bill/114th-congress/house-bill/2 (accessed 2 Jun 2015)

14 Hirsch JA, Harvey HB, Barr RM, et al. Sustainable growth rate repealed, MACRA revealed: historical context and analysis of recent changes in Medicare physician payment methodologies. AJNR Am J Neuroradiol 2016;37:210-4.

15 Rosenkrantz AB, Nicola GN, Allen B, et al. MACRA, MIPS, and the new Medicare quality payment program: an update for radiologists. J Am Coll Radiol 2017;14:316-23.

16 Rosenkrantz AB, Hirsch JA, Allen B, et al. The proposed MACRA/MIPS threshold for patient-facing encounters: what it means for radiologists. J Am Coll Radiol 2017; 14:308-15.

17 Hirsch JA, Leslie-Mazwi TM, Patel AB, et al. MACRA: background, opportunities and challenges for the neurointerventional specialist. J Neurointerv Surg 2016:8:868-74.

18 Hirsch JA, Rosenkrantz AB, Ansari SA, et al. MACRA 2.0: are you ready for MIPS? J Neurointerv Surg 2017;9:714-6.

19 Manchikanti L, Helm li S, Benyamin RM, et al. A critical analysis of Obamacare: affordable care or insurance for many and coverage for few? Pain Physician 2017:20:111-38

20 Rosenkrantz AB, Nicola GN, Hirsch JA. Anticipated impact of the 2016 federal election on federal health care legislation. J Am Coll Radiol 2017;14:490-3.

21 Hirsch JA, Rosenkrantz AB, Nicola GN, et al. Contextualizing the first-round failure of the AHCA: down but not out. J Neurointerv Surg 2017:9:595-600.

22 UCSE/UC Hastings consortium. ACA Repeal and Replace Legislative Timeline. 2017 http://www.healthreformtracker.org/ahca-timeline/ (accessed 20 Aug 2017).

23 The New York Times. House clears path for repeal of health law. $2017 \mathrm{https}: / / \mathrm{www}$. nytimes.com/2017/01/13/us/politics/affordable-care-act-congress-budget.html?_r=0 (accessed 27 Mar 2017).

24 The White House. Executive order minimizing the economic burden of the Patient Protection and Affordable Care Act pending repeal. https://www.whitehouse.gov/ the-press-office/2017/01/2/executive-order-minimizing-economic-burden-patientprotection-and (accessed 2 Apr 2017).

25 Health Affairs Blog. The CBO's updated estimate Of the AHCA. http://healthaffairs.org/ blog/2017/06/06/the-cbos-updated-estimate-of-the-ahca/ (accessed 30 Aug 2017).

26 Health Affairs Blog. Making sense of 'Invisible Risk Sharing'. http://healthaffairs. org/blog/2017/04/12/making-sense-of-invisible-risk-sharing/ (accessed 20 Aug 2017).

27 MacArthur Amendment. Sec. 136. Permitting states to waive certain ACA requirements to encourage fair health insurance premiums. http://docs.house.gov/ billsthisweek/20170424/MacArthur\%20Amendment.pdf (accessed 20 Aug 2017)

28 Upton Amendment. Amendment to H.R. 1628 offered by Mr Upton of Michigan, Mr Long of Missouri, Mr Young of lowa, Mr Valadao of California, Mr Knight of California, Mr Denham of California, and Mrs McMorris Rodgers of Washington. http://docs. house.gov/billsthisweek/20170501/Upton\%20Amendment.pdf (accessed 20 Aug 2017).

29 https://www.cotton.senate.gov/files/documents/170622SENATEHEALTHCARE.pdf (accessed 20 aug 2017)

30 Congressional Budget Office. H.R. 1628, Better Care Reconciliation Act of 2017. https://www.cbo.gov/publication/52849 (accessed 20 Aug 2017).

31 Money Box. The Senate's new health care bill is a win for Ted Cruz-and almost nobody else. http://www.slate.com/blogs/moneybox/2017/07/13/the_senate_s_new_ health_care_bill_is_a_win_for_ted_cruz.html (accessed 20 Aug 2017).

32 The New York Times. Health care overhaul collapses as two Republican Senators defect. https://www.nytimes.com/2017/07/17/us/politics/health-care-overhaulcollapses-as-two-republican-senators-defect.html (accessed 20 Aug 2017)

33 Politico. Trump says he plans to 'let Obamacare fail'. http://www.politico.com/story/ 2017/07/18/trump-tweet-obamacare-repeal-failure-240664 (accessed 20 Aug 2017)

34 The New York Times. John McCain has brain cancer, Senator's office says. 2017 https://www.nytimes.com/2017/07/19/us/politics/john-mccain-brain-cancer.html (accessed 21 Aug 2017).

35 https://www.budget.senate.gov/imo/media/doc/07.18.2017\%20Section \%20by\% 20Section\%20Summary\%20LYN17479.pdf (accessed 21 Aug 2017)

36 https://www.budget.senate.gov/imo/media/doc/BCRA\%20Section $\% 20$ by $\%$ 20Section\%20Summary\%20ERN17500.pdf (accessed 21 Aug 2017)

37 https://www.budget.senate.gov/imo/media/doc/HealthCareFreedomAct.pdf (accessed 21 Aug 2017).

$38 \mathrm{https}: / /$ www.alexander.senate.gov/public/index.cfm/pressreleases?ID=8924A7D6 786A-47C6-8C7F-D97C7E3FC8FA (accessed 21 Aug 2017)

39 The Hill. Freedom Caucus seeks to force ObamaCare repeal vote. http://thehill.com/ policy/healthcare/346158-freedom-caucus-seeks-to-force-obamacare-repeal-vote (accessed 22 Aug 2017).

$40 \mathrm{https}: / /$ www.lgraham.senate.gov/public/index.cfm/press-releases?/D=41EA5BF234A5-45DF-BC5F-C8CE15B8BB53 (accessed 22 Aug 2017)

41 The Atlantic. Why so many Democrats are embracing single-payer health care. https:// www.theatlantic.com/politics/archive/2017/07/healthcare-congress-bernie-sanderssingle-payer-obamacare/533595/ (accessed 4 Sep 2017).

42 Suozzi T. Suozzi, Problem Solvers Caucus releases first bipartisan proposal to make health care system work better for Americans. https://suozzi.house.gov/media/pressreleases/suozzi-problem-solvers-caucus-releases-first-bipartisan-proposal-make-health (accessed 22 Aug 2017)

43 Centers for Medicare and Medicaid Services (CMS). https://innovation.cms.gov (accessed 14 Mar 2017)

44 Hirsch JA, Rosenkrantz AB, Liu RW, et al. The episode, the PTAC, cost, and the neurointerventionalist. J Neurointerv Surg 2017;9:1146-8.

45 Hirsch JA, Leslie-Mazwi TM, Barr RM, et al. The bundled payments for care improvement initiative. J Neurointerv Surg 2016;8:547-8.

46 Health Affairs Blog. Medicare accountable care organization results for 2015: the journey to better quality and lower costs continues. $2016 \mathrm{http}: / /$ healthaffairs.org/blog/ 2016/09/09/medicare-accountable-care-organization-results-for-2015-the-journey-tobetter-quality-and-lower-costs-continues/ (accessed 22 Aug 2017).

47 Lewin Group. CMS bundled payments for care improvement initiative models 2-4: year 2 evaluation and monitoring annual report. 2016 https://innovation.cms.gov/ Files/reports/bpci-models2-4-yr2evalrpt.pdf (accessed 22 Aug 2017).

48 Modern Healthcare. CMS cancels two mandatory pay models and scales back a third. $2017 \mathrm{http} / / /$ www.modernhealthcare.com/article/20170815/NEWS/170819935?utm source $=$ modernhealthcare\&utm_medium $=$ email\&utm_content $=$ 20170815-NEWS170819935\&utm_campaign=mh-alert (accessed 15 Aug 2017).

49 The Henry J. Kaiser Family Foundation. Insurer financial performance in the early years of the Affordable Care Act. 2017 http://files.kff.org/attachment/Data-Note-InsurerFinancial-Performance-in-the-Early-Years-of-the-Affordable-Care-Act (accessed 22 Aug 2017)

50 HealthCare.gov. What Marketplace health insurance plans cover. https://www. healthcare.gov/coverage/what-marketplace-plans-cover/ (accessed 4 Sep 2017).

51 The Guide to Clinical Preventive Services, 2016. https://www. uspreventiveservicestaskforce.org/Home/GetFileByID/989. (accessed 4 Sep 2017)

52 HealthCare Transaction Advisors. \$3.4 trillion: 2016 US healthcare spending by category. https://hctadvisor.com/2015/11/3-4-trillion-2016-us-healthcare-spendingcategory/ (accessed 22 Aug 2017). 
53 Hirsch JA, Silva E, Nicola GN, et al. The RUC: a primer for neurointerventionalists. J Neurointerv Surg 2014:6:61-4.

54 Donovan WD, Leslie-Mazwi TM, Silva E, et al. Diagnostic carotid and cerebral angiography: a historical summary of the evolving changes in coding and reimbursement in a complex procedure family. J Neurointerv Surg 2014;6:712-7.
55 Rosenkrantz AB, Nicola GN, Allen B, et al. MACRA, alternative payment models, and the physician-focused payment model: implications for radiology. J Am Coll Radiol 2017; 14:744-51. 